\title{
PERBEDAAN KADAR KOLESTEROL DAN TRIGLISERIDA SERUM DARI DARAH YANG DIBEKUKAN SEBELUM DISENTRIFUS DAN YANG LANGSUNG DISENTRIFUS
}

\author{
Analysis of Differences in Serum Cholesterol and Triglyceride Levels from Freezed \\ Blood Before Centrifuge and the Directly Centrifuged
}

\author{
Nur Adi ${ }^{1}$, Jangga ${ }^{2}$, Faedatul Isma. $\mathrm{D}^{3}$ \\ 1, Jurusan Teknologi Laboratorium Poltekkes Kemenkes Makassar \\ ${ }^{2}$ Universitas Mega Rezki \\ ${ }^{3}$ RSUP Dr Wahidin Sudirohusodo Makassar
}

Korespondensi : nuradi.poltekkes.mks@gmail.com

\begin{abstract}
This research is based on the reality in the field when the clinical chemistry examination has differences in treating blood samples, after getting a venous blood sample, the blood is immediately centrifuged without being frozen first in order to shorten the time. This study aims to determine the differences in serum cholesterol and triglyceride levels from blood frozen before being centrifuged and immediately centrifuged. This type of research is a laboratory observation, with a total sample of 20 samples. The study was conducted on March 4-15, 2019 at the Laboratory of the Public Hospital of Massenrempulu Enrekang. In this study the results of cholesterol examination with $t$ count (24.3961) > $t$ table (2.093) were obtained, meaning that there were significant differences in serum cholesterol levels from blood frozen before being centrifuged and immediately centrifuged. And triglyceride examination with t count (22.5573) > t table (2,093), means that there are significant differences in serum triglyceride levels from blood frozen before being centrifuged and immediately centrifuged.
\end{abstract}

Keywords: Cholesterol Levels, Frozen, Triglyceride Levels

\begin{abstract}
ABSTRAK
Penelitian ini dilatar belakangi dari kenyataan di lapangan saat pemeriksaan kimia klinik terdapat perbedaan dalam memperlakukan sampel darah, setelah mendapatkan sampel darah vena, darah langsung disentrifus tanpa dibekukan terlebih dahulu dengan maksud untuk mempersingkat waktu. Penelitian ini bertujuan untuk mengetahui perbedaan kadar kolesterol dan trigliserida serum dari darah yang dibekukan sebelum disentrifus dan yang langsung disentrifus. Jenis penelitian ini bersifat observasi laboratorik, dengan jumlah sampel sebanyak 20 sampel. Penelitian dilakukan pada tanggal 04 - 15 Maret 2019 di Laboratorium RSUD Massenrempulu Enrekang. Pada penelitian ini diperoleh hasil pemeriksaan kolesterol dengan nilai t hitung $(24,3961)>t$ tabel $(2,093)$, berarti ada perbedaan bermakna kadar kolesterol serum dari darah yang dibekukan sebelum disentrifus dan yang langsung disentrifus. Dan pemeriksaan trigliserida dengan nilai $\mathrm{t}$ hitung $(22,5573)>\mathrm{t}$ tabel $(2,093)$, berarti ada perbedaan bermakna kadar trigliserida serum dari darah yang dibekukan sebelum disentrifus dan yang langsung disentrifus.
\end{abstract}

Kata Kunci : Dibekukan , Kadar Kolesterol, Kadar Trigliserida 


\section{PENDAHULUAN}

Lemak adalah salah satu kelompok senyawa organik yang terdapat dalam tumbuhan, hewan atau manusia dan yang sangat berguna bagi kehidupan manusia. Lemak tidak larut dalam air, tetapi larut dalam pelarut organik seperti ester, aseton, kloroform, dan benzena. Lemak merupakan sekumpulan senyawa non heterogen yang meliputi asam lemak dan turunannya, lemak netral (trigliserida), fosfolipid serta sterol. Suatu zat yang kaya akan energi dan sebagai penyumbang energi terbesar dibanding dengan zat gizi makro lainnya (Poedjiadi, A., 2006).

Kolesterol merupakan senyawa lemak kompleks yang dihasilkan oleh tubuh yang mempunyai fungsi antara lain membuat hormon seks, adrenal, membentuk dinding sel dan lain-lain. Karena begitu pentingnya kolesterol sehingga tubuh membuatnya sendiri di dalam hati. Kolesterol dieksresikan keluar dari dalam tubuh melalui getah lambung yaitu dengan cara mempertahankan kolesterol dalam bentuk larutan lewat penggabungan dengan garam - garam empedu. Apabila kolesterol mengalami pengendapan dari larutan tersebut, maka endapan ini akan berbentuk padat yang dikenal sebagai batu empedu (Soeharto I, 2001).

Trigliserida atau yang sering disebut triasilgliserol adalah salah satu jenis lemak yang terdapat dalam darah dan berbagai organ tubuh (Soeharto I, 2001). Trigliserida dibentuk dari gliserol dan lemak yang ada dalam makanan yang dikonsumsi secara berlebihan. Kelebihan kalori diubah menjadi trigliserida yang disimpan dibawah kulit, sehingga asupan kalori yang lebih tinggi dari yang dibutuhkan mampu meningkatkan pembentukan trigliserida (Dalimartha S, 2011). Trigliserida berfungsi sebagai transpor dan penyimpanan lemak, trigliserida juga digunakan sebagai sumber energi utama didalam tubuh salah satunya untuk meyediakan energi bagi proses metabolik (Wowor F.J, 2013).

Peningkatan kadar kolesterol diatas normal disebut hiperkolesterolemia, sedangkan peningkatan kadar trigliserida diatas normal disebut hipertrigliseridemia. Kadar kolesterol dan trigliserida diatas normal dapat menyebabkan terjadinya aterosklerosis yang merupakan penyebab penyakit jantung koroner (Wowor F.J, 2013). Faktor yang dapat mempengaruhi kadar kolesterol dan trigliserida yaitu usia, jenis kelamin, aktifitas fisik dan asupan. Asupan lemak dan karbohidrat yang berlebihan dapat meningkatkan kadar kolesterol dan trigliserida dalam darah. Kolesterol dan trigliserida yang tinggi dapat diatasi dengan cara mengatur asupan. Peningkatan kolesterol dan trigliserida akan menambah risiko terjadinya penyakit jantung dan stroke. Mereka yang mempunyai kolesterol dan trigliserida tinggi juga cenderung mengalami gangguan dalam tekanan darah dan risiko diabetes (Ramadhan. A.J, 2010).

Pemeriksaan kadar kolesterol dan trigliserida adalah uji untuk mengetahui adanya peningkatan kadar kolesterol dan trigliserida dalam darah. Sampel pemeriksaan yang umumnya digunakan dalam pemeriksaan kolesterol dan trigliserida adalah serum dari darah vena. Serum merupakan cairan darah berwarna kuning jernih yang bebas dari sel dan tanpa fibrinogen. Pembuatan serum merupakan proses pra analitik dalam pemeriksaan kadar kolesterol dan trigliserida. Tetapi kesalahan masih sering terjadi pada tahap pra analitik. Kesalahan pada tahap ini memberikan kontribusi paling besar, dengan frekuensi $77,1 \%$ diikuti oleh analitik 7,9\%, dan $15 \%$ oleh paska analitik (Tiwi, 2013).

Tahap pra analitik merupakan salah satu fase penting dari pemeriksaan laboratorium. Salah satunya yaitu cara 
mendapatkan serum . Pada tahap inilah yang menentukan apakah akan diperoleh serum yang baik untuk pemeriksaan kadar kolesterol dan kadar trigliserida. Sehingga fase ini sangat berpengaruh terhadap kualitas serum. Serum diperoleh dari sejumlah darah dimasukkan kedalam tabung dan dibiarkan selama 15 - 30 menit maka darah tersebut akan membeku, lalu disentrifus dengan kecepatan 3000 RPM selama 15 menit dan keluarlah cairan bening berwarna kuning jerami (Nugraha, 2015)

Pembekuan darah terjadi melalui proses fibrinogen diubah menjadi fibrin, maka serum tidak mengandung fibrinogen namun zat -zat lainnya masih tetap terkandung didalamnya (Sadikin M, 2001). Menurut Keputusan Menteri Kesehatan Republik Indonesia Nomor 1792 / MENKES / SK / XII / 2010 tentang pedoman pemeriksaan kimia klinik dalam memperoleh serum, darah dibiarkan membeku terlebih dahulu pada suhu kamar selama 15 - 30 menit, kemudian disentrifus dengan kecepatan 3000 RPM selama 15 menit. Pemisahan serum dilakukan kurang dari 2 jam setelah pengambilan darah.

Tujuan pembuatan serum yang diperoleh dari darah yang dibekukan terlebih dahulu adalah untuk menghindari terjadinya hemolisis yaitu adanya kontaminasi eritrosit kedalam serum yang dapat mempengaruhi kadar lemak yaitu terjadinya fals high (tinggi palsu) dan supaya semua cairan yang terbentuk dari hasil sentrifugasi terperas secara sempurna dan kandungan kadar lemak terurai bersama serum. Sampel yang langsung disentrifus sebelum dibekukan menyebabkan kandungan lemak belum terlepas sepenuhnya sehingga dapat mempengaruhi kadar lemak (Nugraha, 2015).

Kenyataan di lapangan saat pemeriksaan kimia klinik terdapat perbedaan dalam memperlakukan sampel darah, setelah mendapatkan sampel darah vena, darah langsung disentrifus tanpa dibekukan terlebih dahulu dengan maksud untuk mempersingkat waktu. Kejadian ini sebenarnya tidak sesuai dengan prosedur yang ada.

Berdasarkan uraian sebelumnya, peneliti tertarik untuk melakukan penelitian tentang analisis perbedaan kadar kolesterol dan trigliserida serum dari darah yang dibekukan sebelum disentrifus dan yang langsung disentrifus.

\section{METODE}

Jenis penelitian ini adalah penelitian bersifat observasi laboratorik yang bertujuan untuk mengetahui perbedaan kadar kolesterol dan trigliserida serum dari darah yang dibekukan sebelum disentrifus dan yang langsung disentrifus. Tempat pengambilan dan pemeriksaan sampel dilakukan di Laboratorium RSUD Massenrempulu Enrekang pada bulan Maret - April 2019.

\section{Alat dan Bahan}

Alat penelitian pada tahap pra analitik yaitu spoit $5 \mathrm{ml}$, tourniquet, kapas alkohol $70 \%$, kasa kering steril, plester steril, sarung tangan, wadah tahan tusukan, tabung reaksi, rak tabung reaksi, sentrifus. Pada tahap analitik yaitu mikro tube, kuvet, klinipet $100 \mu$ l, tip kuning, ABX Pentra 400. Bahan Penelitian yaitu serum, reagen kolesterol khusus autoanalizer produk Horiba ABX, dan reagen trigliserida khusus autoanalizer produk Horiba ABX

\section{Langkah-Langkah Penelitian}

Tahap pra analitik dilakukan pengambilan darah vena sebanyak $4 \mathrm{ml}$. Setelah darah didapatkan segera dipindahkan pada tabung I dan tabung II masing-masing sebanyak $2 \mathrm{ml}$. Darah pada tabung I dibiarkan membeku selama 30 menit, lalu disentrifus dengan 
kecepatan $3000 \mathrm{rpm}$ selama 15 menit. Sedangkan darah pada tabung II langsung disentrifus dengan kecepatan 3000 rpm selama 15 menit. Darah akan terpisah dengan serum

Tahap analitik dilakukan pembacaan kolesterol dan trigliserida dari sampel serum pada alat

Tahap paska analitik dilakukan pembacaan dan pencatatan hasil kadar kolesterol dan trigliserida.

\section{Pengolahan dan Analisis Data}

Analisis data dari 20 sampel pemeriksaan kadar kolesterol dan trigliserida serum dari darah yang dibekukan sebelum disentrifus dan yang langsung disentrifus diproses dengan uji Dependent Sample $t$ - Test (Paired Sample t - Test)

Dimana hipotesis sebagai berikut :

Ho : $\mu 1=\mu 2$ (Tidak ada perbedaan bermakna kadar kolesterol dan trigliserida serum dari darah yang dibekukan sebelum disentrifus dan yang langsung disentrifus) $\rightarrow$ jika $t$ hitung $<\mathrm{t}$ tabel

$\mathrm{Ha}: \mu 1 \neq \mu 2$ (Ada perbedaan bermakna kadar kolesterol dan trigliserida serum dari darah yang dibekukan sebelum disentrifus dan yang langsung disentrifus) $\rightarrow$ jika $t$ hitung $>t$ tabel

Uji signifikansi dengan $\alpha=0,05$

\section{HASIL}

Hasil pemeriksaan kadar kolesterol serum dari darah yang dibekukan sebelum disentrifus diperoleh kadar kolesterol terendah $80 \mathrm{mg} / \mathrm{dl}$ dan kadar kolesterol tertinggi $233 \mathrm{mg} / \mathrm{dl}$. Sedangkan kadar kolesterol serum dari darah yang langsung disentrifus diperoleh kadar kolesterol terendah $66 \mathrm{mg} / \mathrm{dl}$ dan kadar kolesterol tertinggi $215 \mathrm{mg} / \mathrm{dl}$. Dan hasil pemeriksaan kadar trigliserida serum dari darah yang dibekukan sebelum disentrifus diperoleh kadar trigliserida terendah 61 mg/dl dan kadar trigliserida tertinggi 202 $\mathrm{mg} / \mathrm{dl}$. Sedangkan kadar trigliserida serum dari darah yang langsung disentrifus diperoleh kadar trigliserida terendah $49 \mathrm{mg} / \mathrm{dl}$ dan kadar trigliserida tertinggi $189 \mathrm{mg} / \mathrm{dl}$.

Hasil perhitungan kadar kolesterol serum dari darah yang dibekukan sebelum disentrifus dan yang langsung disentrifus didapatkan $\mathrm{t}$ hitung $(24,3961)>\mathrm{t}$ tabel (2,093), maka Ho ditolak dan Ha diterima, yang berarti bahwa ada perbedaan bermakna kadar kolesterol serum dari darah yang dibekukan sebelum disentrifus dan yang langsung disentrifus.

Hasil perhitungan kadar trigliserida serum dari darah yang dibekukan sebelum disentrifus dan yang langsung disentrifus didapatkan $\mathrm{t}$ hitung $(22,5573)>\mathrm{t}$ tabel $(2,093)$, maka Ho ditolak dan Ha diterima, yang berarti bahwa ada perbedaan bermakna kadar trigliserida serum dari darah yang dibekukan sebelum disentrifus dan yang langsung disentrifus.

\section{PEMBAHASAN}

Penelitian terhadap perbedaan kadar kolesterol dan trigliserida ini berdasarkan perlakuan sampel yaitu darah dibiarkan membeku sebelum disentrifus, dan darah yang langsung disentrifus. Tahap ini merupakan salah satu bagian dari proses pra analitik. Pada tahap awal dilakukan pengambilan sampel darah vena dengan menggunakan 2 tabung reaksi, kemudian dilakukan perlakuan penanganan sampel yang berbeda pada masing-masing tabung. Tabung yang pertama didiamkan selama 30 menit, kemudian disentrifus dengan kecepatan 3000 rpm selama 15 menit, lalu serum yang dihasilkan diperiksa kadar kolesterol dan trigliseridanya. Sedangkan tabung yang kedua langsung disentrifus dengan kecepatan $3000 \mathrm{rpm}$ selama 15 menit, lalu serum yang dihasilkan diperiksa kadar kolesterol dan trigliseridanya. Hasil yang didapatkan kemudian dilakukan uji analisis statistik menggunakan uji Dependent Sample t - 
Test untuk mengetahui ada atau tidak ada perbedaan bermakna kadar kolesterol dan trigliserida serum dari darah yang dibekukan sebelum disentrifus dan yang langsung disentrifus.

Kriteria penerimaan dan penolakan hipotesis adalah bila nilai $\mathrm{t}$ hitung $<\mathrm{t}$ tabel, maka "Ho diterima dan Ha ditolak", sebaliknya bila nilai t hitung > t tabel, maka "Ho ditolak dan Ha diterima". Berdasarkan data yang diperoleh dan setelah dilakukan uji statistik menunjukkan bahwa pada pemeriksaan kolesterol didapatkan t hitung $(24,3961)>$ t tabel $(2,093)$ maka Ho ditolak dan Ha diterima, artinya ada perbedaan bermakna kadar kolesterol serum dari darah yang dibekukan sebelum disentrifus dan yang langsung disentrifus. Sedangkan pada pemeriksaan trigliserida didapatkan $\mathrm{t}$ hitung $(22,5573)>\mathrm{t}$ tabel $(2,093)$ maka Ho ditolak dan Ha diterima, artinya ada perbedaan bermakna kadar trigliserida serum dari darah yang dibekukan sebelum disentrifus dan yang langsung disentrifus.

Pemeriksaan kadar kolesterol dan trigliserida menunjukkan terdapat selisih antara kadar kolesterol dan trigliserida serum dari darah yang dibekukan sebelum disentrifus dan yang langsung disentrifus. Hal ini disebabkan karena pada saat sampel darah langsung disentrifus kandungan lemak yang berada di dalam serum belum terlepas secara sempurna, hal tersebut dapat berpengaruh terhadap kadar lemak (Nugraha, 2015).

Proses pra analitik sangat berpengaruh terhadap pemeriksaan kadar lemak, seperti pemeriksaan kolesterol dan trigliserida. Darah yang langsung disentrifus tanpa melalui proses pembekuan terlebih dahulu akan menghasilkan serum dengan jumlah yang lebih sedikit, dibandingkan dengan darah yang melalui proses pembekuan. Hal tersebut disebabkan karena proses koagulasi yang tidak sempurna, serta kandungan lemak masih terikat di dalam serum.

Sampel darah yang dibekukan sebelum disentrifus lebih baik dibandingkan dengan darah yang langsung disentrifus. Menurut keputusan Menteri Kesehatan Republik Indonesia Nomor 1792/MENKES/SK/XII/2010 tentang Pedoman Pemeriksaan Kimia Klinik dalam memperoleh serum, darah dibiarkan membeku terlebih dahulu pada suhu kamar selama 15 - 30 menit. Darah tersebut kemudian disentrifus dengan kecepatan $3.000 \mathrm{rpm}$ selama 15 menit. Pemeriksaan serum dilakukan kurang dari 2 jam setelah pengambilan spesimen untuk menghindari perubahan dari zat-zat yang terlarut oleh pengaruh hemolisis.

\section{KESIMPULAN}

Berdasarkan hasil penelitian yang telah dilaksanakan terhadap 20 sampel pemeriksaan kadar kolesterol dan trigliserida serum dari darah yang dibekukan sebelum disentrifus dan yang langsung disentrifus dapat disimpulkan :

1. Kadar kolesterol dan trigliserida serum dari darah yang dibekukan sebelum disentrifus lebih tinggi kadarnya dibandingkan dengan yang langsung disentrifus.

2. Pemeriksaan kolesterol menunjukkan nilai $\mathrm{t}$ hitung $(24,3961)>\mathrm{t}$ tabel $(2,093)$, berarti ada perbedaan bermakna kadar kolesterol serum dari darah yang dibekukan sebelum disentrifus dan yang langsung disentrifus.

3. Pemeriksaan trigliserida menunjukkan nilai $\mathrm{t}$ hitung $(22,5573)>\mathrm{t}$ tabel $(2,093)$, berarti ada perbedaan bermakna kadar trigliserida serum dari darah yang dibekukan sebelum disentrifus dan yang langsung disentrifus.

\section{SARAN}


Berdasarkan kesimpulan diatas, maka saran penulis terkhusus bagi tenaga laboratorium yaitu harus melakukan pemeriksaan sesuai dengan prosedur atau standar yang benar, karena kesalahan dalam prosedur kerja mampu mempengaruhi hasil pemeriksaan, seperti pada proses pembuatan serum dari darah yang didapat harus didiamkan atau dibekukan terlebih dahulu sebelum disentrifus karena dapat mempengaruhi hasil pemeriksaan kolesterol dan trigliserida

\section{UCAPAN TERIMA KASIH}

Kami mengucapkan terima kasih kepada, Direktur RSUD Massenrempulu, serta semua pihak yang tidak bisa disebutkan satu persatu.

\section{DAFTAR PUSTAKA}

Dalimartha, S. 2011. 36 Resep Tumbuhan Obat Untuk Menurunkan Kolesterol. Edisi Revisi. Penebar Swadaya. Jakarta.

Nugraha, Gilang. 2015. Panduan Pemeriksaan Laboratorium Hematologi Dasar. CV Trans Info Medika. Jakarta.

Poedjiadi, A. 2006. Dasar-Dasar Biokimia. UI-Press. Jakarta.

Ramadhan, A.J. 2010. Mencermati Berbagai Gangguan Pada Darah dan Pembuluh Darah. DIVA Press. Yogyakarta.

Soeharto I. 2001. Kolesterol dan Lemak Jahat, Koleterol dan Lemak Baik, dan Proses Terjadinya Serangan Jantung dan Stroke. PT. Gramedia Pustaka Utama. Jakarta.

Tiwi, 2013. Penanganan Sampel Lab Yang Tidak Sesuai Standar. (https://id.scribd.com) diakses 11 Februari 2019.

Wowor Fandry Johnkun, Ticoalu Shane H.R, Wongkar Djon. 2013. Perbandingan Kadar Trigliserida Darah Pada Pria Perokok dan Bukan Perokok. Jurnal e-Biomedik (eBM). Volume 1. Nomor 2 Juli 2013:986-990. diakses pada tanggal 18 Desember 2018.

Tabel 1

Hasil pemeriksaan Kadar Kolesterol dan Trigliserida Serum dari Darah yang dibekukan Sebelum Disentrifus dan yang Langsung Disentrifus

\begin{tabular}{cccccc} 
No & $\begin{array}{c}\text { Kode } \\
\text { Sampel }\end{array}$ & $\begin{array}{c}\text { Jenis } \\
\text { Kelamin }\end{array}$ & Umur & $\begin{array}{c}\text { Kadar Kolesterol Serum } \\
(\mathrm{mg} / \mathrm{dl})\end{array}$ & $\begin{array}{c}\text { Kadar Trigliserida Serum } \\
(\mathrm{mg} / \mathrm{dl})\end{array}$ \\
\hline
\end{tabular}




\begin{tabular}{|c|c|c|c|c|c|c|c|}
\hline & & & & $\begin{array}{c}\text { Darah } \\
\text { Sebelum } \\
\text { Disentrifus }\end{array}$ & $\begin{array}{c}\text { Darah } \\
\text { Langsung } \\
\text { Disentrifus }\end{array}$ & $\begin{array}{c}\text { Darah } \\
\text { Sebelum } \\
\text { Disentrifus }\end{array}$ & $\begin{array}{c}\text { Darah } \\
\text { Langsung } \\
\text { Disentrifus }\end{array}$ \\
\hline 1 & A & $\mathrm{P}$ & 32 & 98 & 80 & 70 & 59 \\
\hline 2 & B & $\mathrm{P}$ & 32 & 112 & 97 & 100 & 85 \\
\hline 3 & $\mathrm{C}$ & $\mathrm{P}$ & 27 & 120 & 109 & 98 & 81 \\
\hline 4 & $\mathrm{D}$ & $\mathrm{L}$ & 28 & 121 & 109 & 80 & 62 \\
\hline 5 & $E$ & $\mathrm{P}$ & 37 & 160 & 145 & 175 & 164 \\
\hline 6 & $\mathrm{~F}$ & $\mathrm{~L}$ & 36 & 130 & 118 & 102 & 83 \\
\hline 7 & $\mathrm{G}$ & $\mathrm{L}$ & 60 & 182 & 168 & 150 & 137 \\
\hline 8 & $\mathrm{H}$ & $\mathrm{P}$ & 41 & 230 & 215 & 183 & 171 \\
\hline 9 & $\mathrm{I}$ & $\mathrm{L}$ & 51 & 175 & 161 & 200 & 189 \\
\hline 10 & $\mathrm{~J}$ & $\mathrm{P}$ & 59 & 200 & 183 & 187 & 175 \\
\hline 11 & $\mathrm{~K}$ & $\mathrm{~L}$ & 40 & 85 & 66 & 72 & 54 \\
\hline 12 & $\mathrm{~L}$ & $\mathrm{~L}$ & 49 & 100 & 82 & 61 & 49 \\
\hline 13 & $\mathrm{M}$ & $\mathrm{P}$ & 42 & 233 & 213 & 202 & 183 \\
\hline 14 & $\mathrm{~N}$ & $\mathrm{P}$ & 61 & 80 & 66 & 74 & 60 \\
\hline 15 & $\mathrm{O}$ & $\mathrm{P}$ & 44 & 111 & 91 & 75 & 61 \\
\hline 16 & $\mathrm{P}$ & $\mathrm{L}$ & 34 & 201 & 189 & 181 & 163 \\
\hline 17 & $\mathrm{Q}$ & $\mathrm{L}$ & 45 & 198 & 185 & 100 & 81 \\
\hline 18 & $\mathrm{R}$ & $\mathrm{P}$ & 53 & 167 & 154 & 132 & 115 \\
\hline 19 & $\mathrm{~S}$ & $\mathrm{P}$ & 59 & 105 & 91 & 85 & 71 \\
\hline 20 & $\mathrm{~T}$ & $\mathrm{~L}$ & 35 & 190 & 173 & 144 & 130 \\
\hline \multicolumn{4}{|c|}{$\Sigma$} & 2.998 & 2.695 & 2.471 & 2.173 \\
\hline
\end{tabular}

Tabel 2

Analisis uji Dependent Sample t - Test Hasil Pemeriksaan kadar Kolesterol

\begin{tabular}{ccccc}
\hline Variabel & $\mathrm{N}$ & Mean & t hitung & $\mathrm{t}$ tabel \\
\cline { 1 - 3 } $\begin{array}{c}\text { Darah dibekukan } \\
\text { sebelum disentrifus }\end{array}$ & 20 & 149,90 & & \\
\cline { 1 - 3 } $\begin{array}{c}\text { Darah langsung } \\
\text { disentrifus }\end{array}$ & 20 & 134,75 & & 2,093961 \\
\hline
\end{tabular}

Tabel 3

Analisis uji Dependent Sample t - Test Hasil Pemeriksaan Kadar Trigliserida

\begin{tabular}{ccccc}
\hline Variabel & $\mathrm{N}$ & Mean & t hitung & $\mathrm{t}$ tabel \\
\hline $\begin{array}{c}\text { Darah dibekukan } \\
\text { sebelum disentrifus }\end{array}$ & 20 & 123,55 & & \\
\cline { 1 - 2 } $\begin{array}{c}\text { Darah langsung } \\
\text { disentrifus }\end{array}$ & 20 & 108,65 & & 2,5573 \\
\hline
\end{tabular}

